\title{
Meningkatkan Kemampuan Guru dalam Menyusun Rencana Pelaksanaan Pembelajaran (RPP) Dengan Pembinaan Berkelanjutan SD Negeri 2 Sengkol Kecamatan Pujut Kabupaten Lombok Tengah Semester Genap Tahun Pelajaran 2018/2019
}

\author{
Lalu Muhzar \\ farisjamarung@gamail.come
}

\begin{abstract}
Abstrak. Penelitian ini merupakan penelitian tindakan sekolah yang bertujuan untuk mendeskripsikan pembinaan berkelanjutan dapat meningkatkan aktivitas serta kemampuan guru dalam menyusun RPP di SD Negeri 2 Sengkol. Rumusan masalah yang tersusun dalam penelitian ini adalah apakah melalui pembinaan berkelanjutan dapat meningkatkan aktivitas serta kemampuan guru dalam menyusun Rencana Pelaksanaan Pembelajaran. Penelitian tindakan sekolah ini dilaksanakan selama 3 bulan yaitu pada bulan September 2018 sampai dengan bulan Nopember 2018 Siklus I dilaksanakan pada bulan September 2018 dan Siklus II pada Bulan Nopember 2018. Penelitian ini dirancang dengan dua siklus, masing-masing siklus terdiri dari 4 tahapan, yaitu perencanaan, tindakan, pengamatan, dan refleksi. Teknik pengumpulan data menggunakan tugas tertulis dan lembar observasi. Hasil penelitian menunjukkan bahwa kemampuan menyusun RPP dari siklus I dan siklus II mengalami peningkatan. Hal ini ditunjukkan dari data diperoleh selama melaksanakan siklus I aktivitas guru sebesar 3 orang atau 27,27\% kategori sangat aktif , sebanyak 5 orang atau 45,46\% kategori aktif, dan 3 orang atau 27,27\% kurang aktif, sedangkan pada siklus II yang sangat aktif 3 orang atau $27,27 \%$, katagori aktif 8 orang atau $72,73 \%$, sehingga kemampuan guru dalam menyusun RPP dalam siklus I sebesar 2 orang dan siklus II sebesar 6 orang yang ditunjukkan dengan pencapaian nilai 71 - 85 dan 5 orang yang ditunjukkan dengan pencapaian nilai $86-100$.
\end{abstract}

\section{Kata Kunci: Ketrampilan Guru, Pembinaan Berkelanjutan, RPP}

\section{PENDAHULUAN}

Di dalam suatu masyarakat, guru dipandang orang yang serba bisa, mumpuni dibidang apa saja, oleh karena itu guru harus mampu menunjukkan berfikir cerdas, berkepribadian mulia, budi pekerti luhur, perilaku jujur, dan memiliki rasa sosial yang nyata.

Kaitannya dengan tugas seorang guru sebagai pendidik, maka guru harus mampu mengembangkan profesinya dengan kompetensi yang dipahami dan dilaksanakan. Berbagai program dalam rangka meningkatkan profesionalisme guru telah dilaksanakan oleh pemerintah, baik yang berupa program pendidikan dan pelatihan, workshop, seminar ataupun bimbingan teknik, namun hal ini belum bisa menjangkau kesemua guru, sehingga hasilnya belum optimal. Salah satu diantara indikator profesionalisme guru adalah kemampuan keterampilan dalam menyusun rencana pelaksanaan pembelajaran.

Dalam standar kompetensi guru kelas $\mathrm{SD}$, pada kompetensi pedagogik diantaranya bahwa guru harus mampu (1) memahami prinsip-prinsip perancangan pembelajaran, (2) mengembangkan komponen-komponen rancangan pembelajaran, (3) menyusun rancangan pembelajaran yang lengkap, baik untuk kegiatan di dalam kelas, laboratorium maupun lapangan, (4) melaksanakan pembelajaran yang mendidik di kelas, di laboratorium dan di lapangan.

Menurut permendiknas RI nomor 16 Tahun 2007 tentang standar proses, ini sudah menjelaskan bahwa guru harus memahami, mengembangkan, menyusun rencana pelaksanan pembelajaran dan melaksanaknnya sesuai ketentuan yang termuat dalam peraturan tersebut, tetapi pada kenyataannya guru belum mampu menggunakan renacana pelaksanaan 
pembelajaran buatan sendiri. Rencana pelaksanaan pembelajaran yang digunakan dalam proses pembelajaran adalah buatan dari suatu percetakan tertentu atau rencana pelaksanaan pembelajaran yang dibuat lewat forum $\mathrm{KKG}$ tanpa ada perubahan yang disesuaikan dengan situasi dan kondisi sekolah masing-masing serta karakteristik peserta didik. Hal ini terjadi karena rendahnya kemampuan guru dalam menyusun rencana pelaksanaan pembelajaran.

Kurang mampunya guru dalam menyusun rencana pelaksanaan pembelajaran ini disebabkan oleh berbagai faktor, diantara faktor tersebut antara lain karena guru kelas terlalu syarat administrasi, sehingga untuk menyelesaikan administrasi tersebut guru mencari jalan praktis, informasi guru yang diterima lewat pendidikan dan pelatihan belum tuntas secara mendalam sehingga pemahaman materi tentang penyusunan merancang rencana pelaksanaan pembelajaran masih mengembang, kesibukan guru diluar kedinasan tidak bisa ditinggalkan sehingga guru tidak ada kesempatan untuk mempelajari maupun merancang sendiri rencana pelaksanan pembalajaran di rumah. Hal ini diperoleh lewat tanya jawab secara lisan antara kepala sekolah dengan guru kelas.

Selain kemampuan guru rendah, faktor lain yang menyebabkan kurang mampunya guru dalam menyusun rencana pelaksanan pembelajaran adalah belum adanya pembinaan secara berkelanjutan dari kepala sekolah. Sepanjang ini pembinaan yang dilakukan kepala sekolah baik lewat supervisi kelas maupun rapat sekolah masih bersifat umum belum menunjukkan spesifikasi administrasi tertentu yang harus disempurnakan misalnya penyusunan rencana pelaksanaan pembelajaran.

Menurut pengamatan Penulis selaku kepala sekolah, permasalahan tersebut dialami guru-guru di SD Negeri 2 Sengkol Kecamatan Pujut Kabupaten Lombok Tengah. Dari sejumlah guru yang mengajar di SD Negeri 2 Sengkol, guru yang membuat rencana pelaksanaan pembelajaran sendiri hanya 30\% sedangkan $70 \%$ guru dalam penyusunan atau membuat rencana pelaksanaan pembelajaran masih menggunakan rencana pelaksanaan pembelajaran yang di cetak atau buatan bersama dalam forum KKG.

Agar permasalahan tersebut tidak berkepanjangan dan ada solusi pemecahannya maka diperlukan adanya upaya pengentasannya melalui program pembinaan berkelanjutan terhadap kompetensi guru dalam menyusun rencana pelaksanaan pembelajaran yang sesuai dengan kaidahkaidah penyusunan yang benar.

Berdasarkan rumusan masalah diatas, maka tujuan penelitian ini adalah dapat mendekripsikan pembinaan berkelanjutan untuk meningkatkan aktivitas guru dalam menyusun rencana pelaksanaan pembelajaran di SD Negeri 2 Sengkol dan untuk mengetahui apakah melalui pembinaan berkelanjutan dapat meningkatkan ketrampilan guru dalam menyusun rencana pelaksanaan pembelajaran di SD Negeri 2 Sengkol.

Penelitian ini di harapkan dapat memberikan peningkatkan pemahaman ,ketrampilan ,motivasi, serta kompetensi guru tentang sistematika dalam mengembangkan rencana pelaksanaan pembelajaran sesuai dengan kaidah-kaidah penyusunan yang benar; juga sebagai dasar bagi Kepala Sekolah dalam menetukan kebijakan yang berkaitan dengan permasalahan penyusunan rencana pelaksanaan pembelajaran yang dibuat oleh guru-guru untuk pelaksanaan pembelajaran di kelas.

\section{LANDASAN TEORI DAN KAJIAN PUSTAKA}

Pembinaan berkelanjutan mempunyai hubungan yang sangat erat dengan supervisi, sebab didalam melaksanakan supervisi pasti akan diadakan suatu pembinaan dalam kata lain bahwa pembinaan merupakan salah satu embrio dari supervisi.

Menurut kamus besar bahasa Indonesia, Depdikbud (2000), supervisi adalah mengawasi, mengamati, meneliti. Menurut kamus bergambar, Sinergi pustaka Indonesia (2007), supervisi adalah pengawasan utama, pengontrolan tertinggi, sedangkan pengertian supervisi menurut Suharsimi Arikunto (2004), ada empat 
pengertian supervisi, secara singkat dapat diartikan sebagai berikut : (1) Inspeksi, yaitu melihat untuk mencari kesalahan, (2) pemeriksaan, yaitu melihat apa yang terjadi dalam kegiatan, (3) pengawasan dan penilaian, melihat mana yang positif dan mana yang negatif, (4) supervisi, melihat bagian mana dari kegiatan di sekolah yang masih negatif untuk diupayakan menjadi positif, dan melihat mana yang sudah positif untuk dapat ditingkatkan menjadi lebih positif lagi, yang penting adalah pembinaan.

Menurut Kamus Besar Indonesia, Depdikbud (2000), membina adalah membangun, mendirikan, sedanagkan pembinaan adalah (1) proses, perbuatan, cara membina, (2) pembaharuan, penyempurnaan, (3) usaha tindak dan kegiatan yang dilakukan secara berdayaguna dan berhasil guna untuk memperoleh hasil lebih baik.

Pembinaan berkelanjutan adalah tindakan dan kegiatan yang dilakukan secara berdayaguna dan berhasil guna untuk memperoleh hasil yang lebih baik yang dilakukan/berlangsung terus-menerus dan berkesinambungan.

Pembinaan berkelanjutan dalam penelitian ini tindakan sekolah ini adalah tindakan dan kegiatan proses pembinaan yang dilakukan terus menerus, berkesinambungan, berdayaguna dan berhasil guna untuk memperoleh hasil yang lebih baik yang dilakukan oleh kepala sekolah terhadap guruguru di sekolah. Pembinaan pada penelitian ini difokuskan pada penyusunan rencana pelaksanaan pembelajaran (RPP), sebab perencanaan pembelajaran merupakan bagian penting dalam pelaksanaan pendidikan di sekolah. Melalui perencanaan pembelajaran yang baik, guru akan lebih mudah dalam melaksanakan pembelajaran.

\section{METODE PENELITIAN}

Subyek penelitian ini adalah seluruh guru pengajar di SD Negeri 2 Sengkol Tahun Pelajaran 2018/2019 yang berjumlah 11 orang guru yang terdiri dari 7 orang guru PNS dan 4 orang guru tidak tetap (GTT) . Dalam penelitian ini sebagai subyek penelitian adalah guru pengajar di SD Negeri 2 Sengkol, hal ini dikarenakan guru dalam penyusunan suatu racangan pelaksanaan pembelajaran kwalitasnya masih rendah, sehingga perlu adanya pembinaan supaya dalam pembelajarannya guru bisa menyusun rencana pelaksanaan pembelajaran dengan benar.

Prosedur penelitian tindakan sekolah ini dilaksanakan melalui proses pengkajian berdaur yang terdiri dari 4 tahap, yaitu merencanakan (Planning), melakukan tindakan (Acting), mengamati (Observasing), dan refleksi (Reflecting).

Perencanaan :

1) Menyiapkan program supervisi atau pembinaan;

2) Menetapkan pengawas sekolah sebagai observer;

3) Mendesain kelompok;

4) Menyiapkan instrumen supervisi;

5) Menyiapkan angket.

Tindakan :

Pelaksanaan tindakan dalam siklus I adalah sebagai berikut : sesuai dengan perencanaan yang peneliti rancang dengan dasar data awal hasil supervisi sebelum ada tindakan, peneliti mengadakan pembinaan berkelanjutan secara kelompok dengan langkah-langkah sebagai berikut :

1) Diawali dengan penyampaian tujuan pembinaan, peneliti membagi angket rancangan pelaksanaan pembelajaran yang harus diisi oleh guru-guru SD Negeri 2 Sengkol sebagai responden selama 10 menit;

2) Dasar data kondisi awal dan hasil angket peneliti melakukan pembinaan dengan menjelaskan cara penyusunan rencana pelaksanaan pembelajaran yang meliputi prinsip-prinsip penyusunan rencana pelaksanaan pembelajaran, komponenkomponen rencana pelaksanaan pembelajaran, langkah-langkah penysunan rencana pelaksanaan pembelajaran selama 50 menit;

3). Guru atau responden diberi tugas menyusun rencana pelaksanaan

pembelajaran selama 30 menit.

Observasi yang dilakukan dalam siklus I ini meliputi :

1) Peneliti bersama observer mengamati keaktifan guru dalam mengikuti 
pembinaan dengan instrumen lembar pengamatan;

2) Peneliti bersama observer meneliti angket yang sudah diisi oleh guru atau responden;

3) Peneliti mengamati rencana pelaksanaan pembelajaran yang telah dibuat guru pada siklus I.

Refleksi :

Dari hasil observasi peneliti memperoleh data, langkah selanjutnya adalah membadingkan antara data yang diperoleh setelah adanya tindakan siklus I yaitu diadakan pembinaan secara kelompok. Dari perbandingan tersebut dapat dilihat apakah hasil pembinaan pada siklus I terjadi peningkatan motivasi dan kemampuan guru dalam menyusun rencana pelaksanaan pembelajaran atau tidak, jika terjadi suatu peningkatan namun belum memenuhi indikator keberhasilan yang diharapkan maka dilakukan perbaikan lagi pada pelaksanaan tindakan siklus II.

\section{HASIL PENELITIAN \\ DAN \\ PEMBAHASAN \\ Hasil Siklus I}

Siklus I dilaksanakan pada tanggal 4 Septembver 2018 yang diiikuti oleh 11 orang guru SD Negeri 2 Sengkol dengan rencana program pembinaan yang telah disusun serta dibantu oleh Hj.Sofiah, S.Pd.SD sebagai observer, dengan hasil sebagai berikut :

Setelah dilakukan pembinaan secara berkelompok pada siklus I, diperoleh bahwa terjadi peningkatan yang signifikan aktivitas guru dalam penyusunan RPP dibanding sebelum dilakukan siklus I. Hal ini dapat ditunjukkan pada tabel

Tabel 1. Aktivitas Guru Siklus I

\begin{tabular}{|c|c|c|c|c|c|}
\hline \multirow[b]{2}{*}{ No } & \multirow[b]{2}{*}{ Aktivitas Guru } & \multicolumn{2}{|c|}{ Pra Siklus } & \multicolumn{2}{|c|}{ Siklus I } \\
\hline & & Jml. Guru & $\%$ & $\begin{array}{l}\text { Jml. } \\
\text { Guru }\end{array}$ & $\%$ \\
\hline 1 & Sangat Aktif & 0 & $0,0 \%$ & 3 & $27,27 \%$ \\
\hline 2 & Aktif & 0 & $0,0 \%$ & 5 & $45,46 \%$ \\
\hline 3 & Kurang Aktif & 8 & $72,73 \%$ & 3 & $27,27 \%$ \\
\hline 4 & Tidak Aktif & 3 & $27,27 \%$ & 0 & $0,0 \%$ \\
\hline & Jumlah & 11 & $100 \%$ & 11 & $100 \%$ \\
\hline
\end{tabular}

Dari tabel diatas menunjukkan aktivitas guru dalam penyusunan RPP meningkat dari sebelum siklus, guru yang sangat aktif dalam pembinaan sebelum dilakukan siklus I tidak ada, setelah siklus I menjadi 3 orang guru yang sangat aktif, pada sebelum siklus aktifitas guru yang tergolong dalam kategori aktif tidak ada, setelah dilakukan siklus I menjadi 5 orang guru, dan guru yang sebelum siklus I sebanyak 8 orang memiliki aktifitas yang kurang setelah dilakukan siklus I menjadi 3 orang, serta sebanyak 3 orang yang tidak aktif dalam pembinaan sebelum siklus, kemudian setelah diadakan siklus I tidak ada lagi guru yang tidak aktif. Akan lebih jelasnya bila disajikan dalam grafik berikut ini :

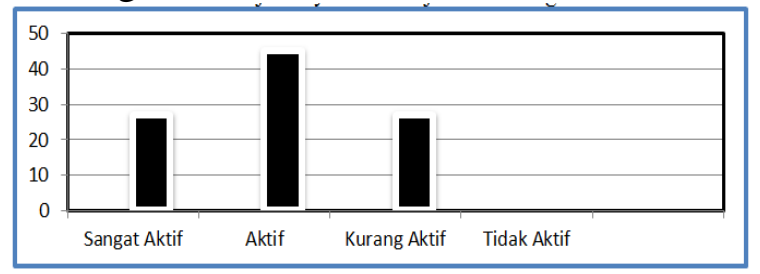

Grafik 1. Aktivitas Guru dalam

Pembinaan siklus I

Ketrampilan Menyusun RPP

Dalam pelaksanaan penyusunan RPP siklus I melalui pembinaan berkelanjutan ternyata dapat meningkatkan ketrampilan Guru dalam menyusun Rencana Pelaksanaan Pembelajaran (RPP), hal ini dibuktikan dengan hasil karya guru dalam menyusun RPP yang kemudian dinilai oleh peneliti, hasil tersebut dapat dilihat seperti pada tabel berikut ini :

Tabel 3. Hasil Tes Siklus I

\begin{tabular}{|c|c|c|c|}
\hline \multirow{2}{*}{ No } & \multirow{2}{*}{ Rentang Nilai } & \multicolumn{2}{|c|}{ Banyaknya Guru } \\
\cline { 3 - 4 } & & Pra Siklus & Siklus I \\
\hline 1 & $0-40$ & 0 & 0 \\
\hline 2 & $41-55$ & 7 & 0 \\
\hline 3 & $56-70$ & 4 & 6 \\
\hline 4 & $71-85$ & 0 & 5 \\
\hline 5 & $86-100$ & 0 & 0 \\
\hline \multicolumn{2}{|c|}{ Jumlah } & \multicolumn{2}{|c|}{} \\
\hline
\end{tabular}

Dari tabel di atas menunjukkan bahwa terdapat peningkatan hasil karya guru dalam menyusun RPP yang dibuktikan dengan pencapaian nilai yang meningkat, yaitu sebelum dilakukan siklus I nilai karya guru dalam menyusun RPP yang memperoleh nilai 41-45 sebanyak 7 orang, setelah dilakukan siklus I tidak ada lagi yang mendapat nilai 4145 , begitu juga guru yang memperoleh nilai 56-70 sebelum dilakukan siklus I sebanyak 4 orang setelah siklus I menjadi 6 orang, guru yang mendapat nilai 71-85 sebelum dilakukan Siklus I tidak ada, setelah dilakukan Siklus I menjadi 5 orang.

\section{Hasil Siklus II}


Dari hasil refleksi siklus I yang diperoleh bahwa masih terdapat tingkat aktivitas guru dalam pembinaan menyusun RPP yang masih kurang aktif sehingga perlu dilakukan siklus II. Setelah diadakan siklus II terdapat peningkatan aktifitas guru dalam menyusun RPP melalui pembinaan berkelanjutan. Hal ini dapat dilihat dalam tabel berikut ini :

Tabel 4. Aktifitas Guru pada Siklus II

\begin{tabular}{|c|l|c|c|c|c|}
\hline \multirow{2}{*}{ No } & \multirow{2}{*}{$\begin{array}{c}\text { Aktivitas } \\
\text { Guru }\end{array}$} & \multicolumn{2}{|c|}{ Pra Siklus } & \multicolumn{2}{c|}{ Siklus II } \\
\cline { 3 - 6 } & Jml. Guru & $\mathbf{0}$ & $\begin{array}{c}\text { Jml. } \\
\text { Guru }\end{array}$ & $\mathbf{\%}$ \\
\hline 1 & Sangat Aktif & 0 & $0,0 \%$ & 3 & $27,27 \%$ \\
\hline 2 & Aktif & 0 & $0,0 \%$ & 8 & $72,73 \%$ \\
\hline 3 & Kurang Aktif & 8 & $72,73 \%$ & 0 & $0,0 \%$ \\
\hline 4 & Tidak Aktif & 3 & $27,27 \%$ & 0 & $0,0 \%$ \\
\hline \multicolumn{2}{|c|}{ Jumlah } & 11 & $100 \%$ & 11 & $100 \%$ \\
\hline
\end{tabular}

Dari tabel di atas menunjukkan aktivitas Guru dalam menyusun RPP meningkat dari sebelum siklus guru yang sangat aktif dalam menyusun RPP tidak ada setelah siklus I dan perbaikan siklus II meningkat menjadi 3 orang guru yang sangat aktif, sebelum siklus dilakukan aktivitas guru yang tergolong dalam kategori aktif tidak ada, setelah dilakukan siklus I dan perbaikan siklus II menjadi 8 orang guru yang dikategorikan aktif dalam menyusun RPP, guru yang sebelum siklus I sebanyak 8 orang memiliki aktivitas yang kurang setelah dilakukan siklus II tidak ada lagi, serta sebanyak 3 orang guru yang tidak aktif dalam pembinaan menyusun RPP sebelum siklus, kemudian setelah diadakan siklus I dan perbaikan siklus II tidak ada lagi. Hal ini membuktikan bahwa terjadi peningkatan yang signifikan dalam aktivitas guru dalam menyusun Rencana Pelaksaan Pembelajaran (RPP) setelah dilakukan pembinaan berkelanjutan.

Ketrampilan Menyusun RPP

Setelah melakukan perbaikan siklus I dan kemudian dilakukan siklus II melalui pembinaan berkelanjutan, kemampuan guru dalam menyusun RPP mengalami peningkatan yang signifikan. Peningkatan kemampuan guru dalam menyusun RPP ini ditunjukkan dengan pencapaian hasil karya.

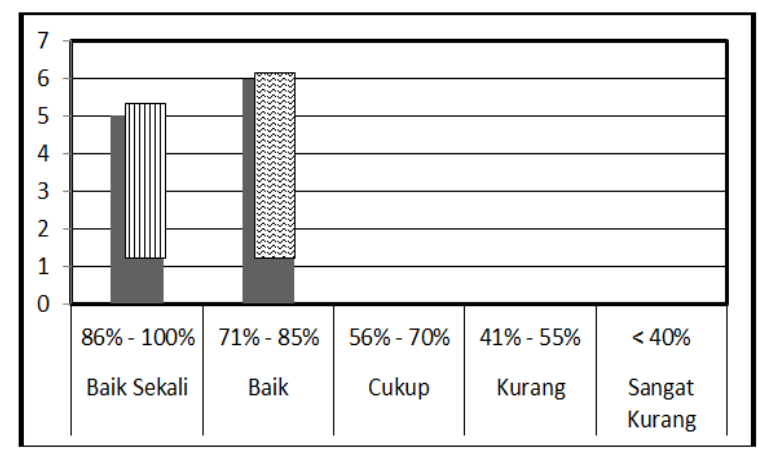

Dari data tersebut di atas dapat dilihat bahwa dalam penyusunan Rencana Pelaksanaan Pembelajaran (RPP) sudah berjalan dengan baik, namun masih ada guru yang belum memahami atau mengikuti pembinaan dalam menyusun RPP tersebut sehingga diperoleh kemampuan guru yang kurang memuaskan dalam menyusun RPP.

Beberapa hal yang perlu diperhatikan sehubungan dengan pengamatan observer, diantaranya hasil pengamatan terhadap peneliti oleh observer ditemukan bahwa peneliti dalam melaksanakan pembinaan berkelanjutan kepada guru tentang penyusunan Rencana Pelaksanaan Pembelajaran (RPP), peneliti masih kurang bisa memancing semangat guru untuk mengikuti pembinaan dalam menyusun RPP, peneliti kurang jelas dalam menerangkan poin-poin penting dalam menyusun RPP, sehingga guru kurang menangkap materi pembinaan. Namun secara garis besar penggunaan pembinaan berkelanjutan dalam menyusun RPP ini sudah dapat memberi respon positif yang intinya dapat meningkatkan kemampuan guru dalam menyusun Rencana Pelaksanaan Pembelajaran (RPP) secara mandiri. Hal ini dapat dibuktikan dengan nilai yang diperoleh guru dalam menyusun RPP. Pada siklus I diperoleh nilai rata-rata sebesar 67,5 dan siklus II diperoleh nilai rata-rata klasikal sebesar 78,1, ini membuktikan bahwa terjadi peningkatan yang signifikan dengan adanya pembinaan berkelanjutan.

Berdasarkan hasil pengamatan serta hasil tes bahwa siklus pertama perlu adanya tindakan perbaikan dalam menyusun Rencana Pelaksanaan Pembelajaran (RPP) melalui pembinaan berkelanjutan perbaikan tersebut diantaranya dalam pelaksanaan pembinaan, 
peneliti secara jelas menjelaskan poin-poin penting dalam menyusun RPP, serta peneliti membimbing dan memotivasi guru dalam menyusun RPP.

Secara garis besar pelaksanaan siklus I berlangsung cukup baik walaupun masih ada guru yang belum sesuai nilai yang diharapkan, tetapi sudah ada peningkatan yang signifikan. Sehingga peneliti perlu mengadakan penyempurnaan pembinaan dalam menyusun RPP dengan mengadakan siklus II.

Setelah dilaksanakan penyempurnaan pembinaan dalam menyusun RPP siklus II terjadi peningkatan aktivitas guru, serta kemampuan guru dalam menyusun Rencana Pelaksanaan Pembelajaran (RPP) secara mandiri dan dapat digunakan dalam proses pembelajaran. Hasil tersebut dapat dilihat dari grafik seperti di bawah ini :

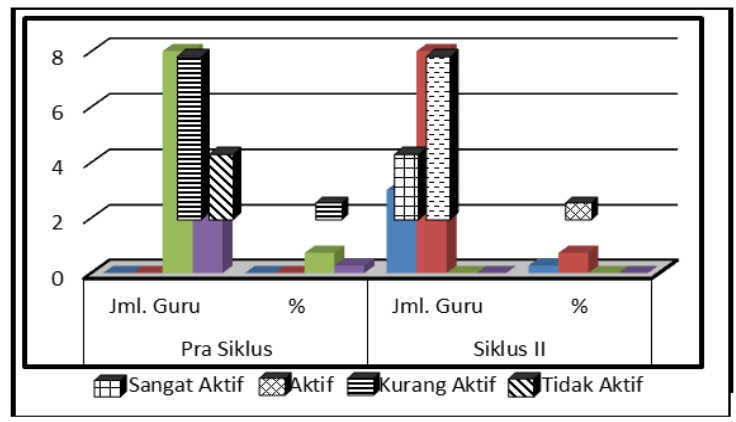

Grafik 4. Aktivitas Guru sebelum siklus sampai siklus II

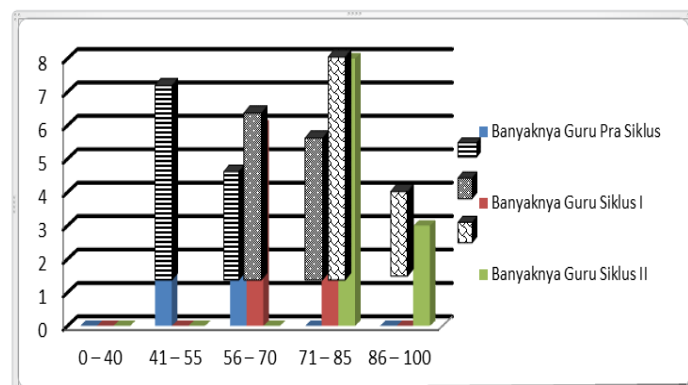

Grafik 5. Ketrampilan Guru dalam menyusun RPP sebelum siklus sampai siklus PENUTUP

Saran

Dari hasil penelitian yang telah dilaksanakan, dapat diambil kesimpulan sebagai berikut: 1) Pembinaan berkelanjutan dapat meningkatkan aktivitas guru mengikuti program; 2) Pembinaan berkelanjutan dapat meningkatkan ketrampilan guru dalam menyusun Rencana Pelaksanaan Pembelajaran di SD Negeri 2 Sengkol.

Saran

1. Guru : hendaknya guru memiliki ketrampilan pembuatan perencanaan pembelajaran baik yang berupa silabus maupun Rencana Pelaksanaan Pembelajaran (RPP), karena perencanaan pembelajaran merupakan perangkat utama yang dipakai guru sebagai acuan dalam melaksanakan pembelajaran.

2. Kepala Sekolah : pembinaan berkelanjutan kepada guru-guru merupakan salah satu alternatif untuk meningkatkan ketrampilan guru dalam menyelesaikan administrasi terutama dalam penyusunan Rencana Pelaksanaan Pembelajaran (RPP) yang standar, oleh karena itu Kepala Sekolah hendaknya melakukan pembinaan secara kontinue.

3. Pengawas : hendaknya mau menerapkan pembinaan berkelanjutan dalam melaksanakan supervisi ke sekolahsekolah guna meningkatkan kemampuan guru terutama dalam menyusun Rencana Pelaksanaan Pembelajaran (RPP).

\section{DAFTAR PUSTAKA}

Arikunto, suharsimi.2006. Penelitian Tindakan Kelas. Jakarta: PT. Bumi Aksara.

Departemen Pendidikan Nasional. 2000. Kamus Besar Bahasa Indonesia.

Departemen Pendidikan Nasional. 2003. Undang-undang Republik IndonesiaNomor 20 Tahun 2003 Tentang Sistem Pendidikan Nasional. Jakarta: Sekretariat Jenderal Departemen Pendidikan Nasional.

Eko Supraptono . 2009. Penyusunan Penelitiaan Tindakan Kelas. Semarang: Gugus Pengelolaan Penelitian dan Pengabdian Masyarakat Fakultas Teknik Universitas Negeri semarang.

Rosilawati, Erwin. 2010. Petunjuk Penyusunan Penelitian Tindakan Sekolah. Semarang: Widyaiswara LPMP.

Sri Naelah, 2013. Peningkatan Kemampuan Guru Dalam Menyusun RPP Melalui 
Pembinaan Berkelanjutan. Lombok

Tengah. (tidak dipublikasikan) 